\title{
The effect of the sex, age, and breed of farmed rabbits and the choice of management system on the extensity and intensity of Eimeria infection
}

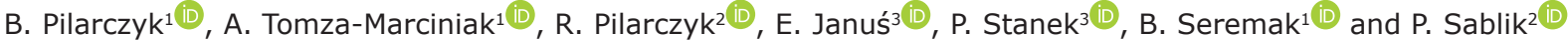

1. Department of Animal Reproduction Biotechnology and Environmental Hygiene, Faculty of Biotechnology and Animal Husbandry, West Pomeranian University of Technology, Szczecin, Poland; 2. Department of Ruminant Science, Faculty of Biotechnology and Animal Husbandry, West Pomeranian University of Technology, Szczecin, Poland; 3. Laboratory for Organic Production of Food of Animal Origin, Institute of Animal Breeding and Biodiversity Conservation, University of Life Sciences in Lublin, Poland.

Corresponding author: A. Tomza-Marciniak, e-mail: agnieszka.tomza-marciniak@zut.edu.pl

Co-authors: BP: bogumila.pilarczyk@zut.edu.pl,RP: renata.pilarczyk@zut.edu.pl,EJ: ewa.janus@up.lublin.pl, PS: piotr.stanek@up.lublin.pl, BS: beata.seremak@zut.edu.pl,PSa: piotr.sablik@zut.edu.pl Received: 07-03-2020, Accepted: 30-06-2020, Published online: 20-08-2020

doi: www.doi.org/10.14202/vetworld.2020.1654-1660 How to cite this article: Pilarczyk $B$, Tomza-Marciniak $A$, Pilarczyk R, Januś E, Stanek P, Seremak B, Sablik P (2020) The effect of the sex, age, and breed of farmed rabbits and the choice of management system on the extensity and intensity of Eimeria infection, Veterinary World, 13(8): 1654-1660.

\begin{abstract}
Background and Aim: The most common causes of loss and diarrhea in rabbit farming are nutritional errors and coccidiosis. The infection can spread rapidly throughout a breeding area, reducing the rabbit population, and causing heavy losses. The aim of the study was to determine the influence of the system of animal management on the extensity and intensity of infection by Eimeria of farmed rabbits, together with the effect of the sex, age, and breed of the rabbits themselves.

Materials and Methods: The study included 91 rabbits (Flemish Giant, New Zealand White, French Lope, Vienna Blue, California White, and mixed breed) from eight domestic (small-scale) farms from Poland. The prevalence and intensity of coccidial infection were determined by the Willis-Schlaf and McMaster coprological methods. The species were determined based on oocyst morphology: Their shape, color, form index, the presence or absence of micropyle and cap, and the presence or absence of residual, polar, and Stiedé bodies.
\end{abstract}

Results: Seven species of Eimeria were isolated from the tested rabbits: Eimeria magna, Eimeria media, Eimeria perforans, Eimeria stiedae, Eimeria coecicola, Eimeria exigua, and Eimeria irresidua. Most infections were found to be of relatively low intensity. No significant differences in the extensity of Eimeria protozoan infection were observed with regard to sex. However, rabbit age had a significant influence on the extensity of infection by E. magna and of Eimerian protozoans combined. The greatest extensity was observed in rabbits aged below 6 months. For all species of Eimeria, greater extensity was observed among rabbits kept in groups than individually. The system of rabbit management also had a significant influence on the intensity of infection. Those kept in groups demonstrated a significantly higher mean intensity of infection of E. magna and all Eimeria species combined than those kept individually.

Conclusion: Our findings indicate that Eimeria protozoa are a common occurrence on small-scale rabbit farms. As coccidiosis treatment does not always give good results, prevention is very important in the fight against this disease. It is necessary to develop a new preventive paradigm that pays special attention to the factors that promote the spread and development of infection in domestic (small-scale) farms from Poland. For example, it would be recommended to use large, dry, bright rooms with access to the sun, as these are conducive to preventing the occurrence of coccidia infections.

Keywords: Eimeria, rabbits, small-scale rabbit farms.

\section{Introduction}

Rabbits are commonly farmed for their meat or hides; however, both juvenile and adult rabbits are subject to invasive diseases and parasite infections. Both can have varying influences on the health of the rabbits and the cost-effectiveness of their farming, and are responsible for the greatest losses. The scale of the problem depends to a certain degree on the intensity of farming, with rabbits kept at high

Copyright: Pilarczyk, et al. Open Access. This article is distributed under the terms of the Creative Commons Attribution 4.0 International License (http://creativecommons.org/licenses/ by/4.0/), which permits unrestricted use, distribution, and reproduction in any medium, provided you give appropriate credit to the original author(s) and the source, provide a link to the Creative Commons license, and indicate if changes were made. The Creative Commons Public Domain Dedication waiver (http:// creativecommons.org/publicdomain/zero/1.0/) applies to the data made available in this article, unless otherwise stated. densities being more seriously affected than those kept individually $[1,2]$.

The most common causes of loss and diarrhea in rabbit farming are nutritional errors and coccidiosis; the latter of which is caused by protozoa of the genus Eimeria. Coccidiosis can occur in intestinal or hepatic forms, and can quickly spread, thanks to the direct and short developmental cycle of coccidians [3]. Young rabbits are the most susceptible to infection, particularly those immediately after weaning, while adult rabbits are often asymptomatic carriers of Eimeria. Clinical coccidiosis is characterized by apathy, chronic, or acute diarrhea, dehydration and reduced weight gain due to poor food use and decreased appetite, often resulting in death [4]. The infection can spread rapidly throughout a breeding area, reducing the rabbit population, and causing heavy losses. 
The majority of rabbits kept commercially in Poland are reared on domestic (small-scale) farms. However, as such fragmentation is typically more prone to biosecurity errors, such systems are at higher risk of the parasite infection. Hence, to minimize the threat of such infection, it is important to use correct biosecurity procedures and to design and implement appropriate prophylactic programs.

The aim of the study was to determine the influence of the system of animal management on the extensity and intensity of infection by Eimeria of farmed rabbits, together with the effect of the sex, age, and breed of the rabbits themselves.

\section{Materials and Methods}

\section{Ethical approval}

The tests were performed on feces samples taken from farmed rabbits. Under Polish law, this study was exempt from the need to obtain Local Ethics Committee approval.

\section{Animals}

The study was conducted from September to November 2019 and included 91 rabbits (Flemish Giant, New Zealand White, French Lope, Vienna Blue, California White, and mixed breed) from eight domestic (small-scale) farms from Poland. The rabbits were kept in cages stored in the open air, under a roof or indoors. The floors of the cages consisted of wooden grates or welded mesh. The rabbits were fed farm fodder consisting of cereals (barley, wheat, and oats), bran, dry roughage (hay), and root crops (carrots, beetroots, and steamed potatoes) as well as green fodder.

\section{Fecal samples}

Feces samples were collected from each animal. For this purpose, plastic sheets were placed under the floor of the cages. Individual fecal samples were collected in plastic bags, transported to the laboratory, and stored at $4{ }^{\circ} \mathrm{C}$ until analysis.

\section{Parasitological analysis}

The prevalence and intensity of coccidial infection were determined by the Willis-Schlaf and McMaster coprological methods [5].

The species were determined based on oocyst morphology: Their shape, color, form index, the presence or absence of micropyle and cap, and the presence or absence of residual, and polar and Stiedé bodies. Identification was also performed based on their time of sporulation, facilitated in a wet chamber at $24-26^{\circ} \mathrm{C}$ in a $2.5 \%$ aqueous solution of potassium dichromate $\left(\mathrm{K}_{2} \mathrm{Cr}_{2} \mathrm{O}_{7}\right)[6]$.

\section{Statistical analysis}

Statistical analysis was performed using Statistica 13.3 software (TIBCO Software Inc., Palo Alto, CA, USA). The influence of selected factors (gender, age, race, housing system, and farm) on the extensity of Eimeria infection was determined with the $\chi^{2}$ test. In addition, the significance of the intensity of infection was evaluated with the Mann-Whitney or Kruskal-Wallis test.

\section{Results}

Seven species of Eimeria were isolated from the tested rabbits: Eimeria magna, Eimeria media, Eimeria perforans, Eimeria stiedae, Eimeria coecicola, Eimeria exigua, and Eimeria irresidua. Detailed data on the extensity of the infection with regard to individual species of Eimeria are presented in Table-1. Most infections were found to be of relatively low intensity (Table-2).

No significant differences in the extensity of Eimeria protozoan infection were observed with regard to sex. However, rabbit age had a significant influence on the extensity of infection by E. magna $\left(\chi^{2}=6.0 ; p=0.04\right)$ and of Eimerian protozoans combined $\left(\chi^{2}=6.7 ; p=0.03\right)$. The greatest extensity was observed in rabbits aged below 6 months (Table-1).

The breed of the farmed rabbits significantly influenced the spread of E. magna $\left(\chi^{2}=21.6 ; \mathrm{p}<0.001\right)$, E. media $\left(\chi^{2}=17.0, \mathrm{p}<0.001\right)$, E. exigua $\left(\chi^{2}=8.7 ; \mathrm{p}=0.04\right)$, and of all the protozoan combined $\left(\chi^{2}=19.7 ; p<0.001\right)$. The highest extensity was observed in New Zealand White and French Lope rabbits, and the lowest in Vienna Blue and Californian White; however, this may be due to the low number of individuals of the latter two. The system of animal management had a significant influence on the extensity of infection by E. magna $\left(\chi^{2}=27.3\right.$; $\mathrm{p}<0.001)$, E. media $\left(\chi^{2}=21.4 ; \mathrm{p}<0.001\right)$, E. stiedae $\left(\chi^{2}=6.8 ; \mathrm{p}<0.01\right)$, E. irresidua $\left(\chi^{2}=4.1 ; \mathrm{p}=0.04\right)$, and all protozoa combined $\left(\chi^{2}=31.5 ; \mathrm{p}<0.001\right)$. For all species of Eimeria, greater extensity was observed among rabbits kept in groups than individually (Table-1).

Significant differences in the mean intensity of $E$. perforans and E. coecicola infection were observed between males and females. A significantly higher intensity of $E$. perforans infection $(\mathrm{Z}=2.17 ; \mathrm{p}=0.03)$ was found among the females, and E. coecicola infection among the males $(\mathrm{U}=4.0 ; \mathrm{p}=0.02)$ (Table-2).

Significant differences in the intensity of infection were observed between the tested age groups for E. magna and combined Eimeria infection. Both demonstrated significantly higher intensity $(\mathrm{p} \leq 0.05)$ among rabbits aged $<6$ months compared to those aged 6-12 months (Table-3).

Similarly, the intensity of infection by $E$. media and total Eimeria was significantly influenced by the breeds of rabbit. The Flemish Giant and New Zealand White rabbits demonstrated significantly higher mean intensity of $E$. media infection than the French Lope and mixed breeds $(p \leq 0.05)$, while the New Zealand Whites displayed significantly higher intensity of infection for all Eimeria combined than the mixed breeds $(\mathrm{p} \leq 0.05)$. The Vienna Blue and California White specimens infected with E. stiedae, E. coecicola, or E. exigua were not included in the statistical analysis due to the very small number of specimens (Table-4). 


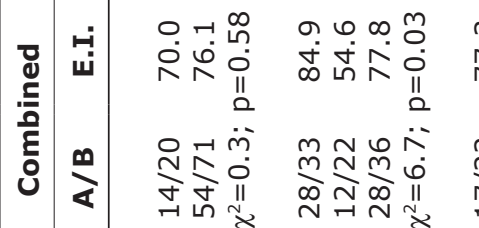

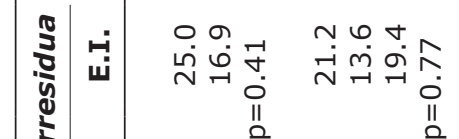

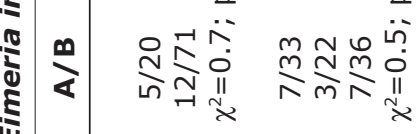

:

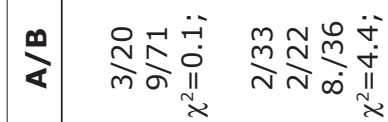

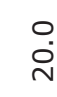

完

o 숭

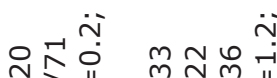

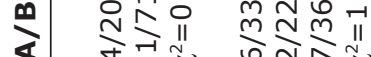

8ี

웅ㅁㅇ

뉜

の 유무 m

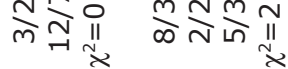

-i $\quad 0 \%$ m mo

ن

N

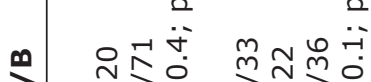

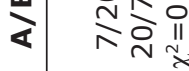

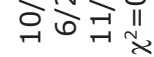

(ิ)

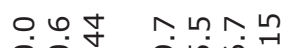

용

ดี่ ค่ं ம்

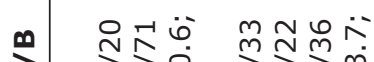

学旁少

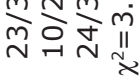

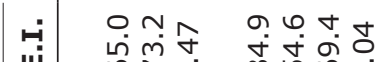

ถู่

迁

유ำ m

ले ㄷํ요 의 곳

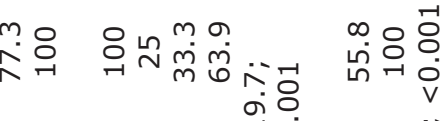

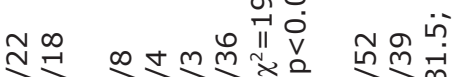

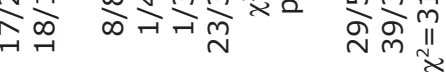

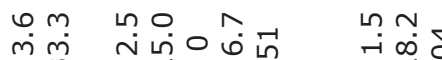

$m$ ᄀ

$N \infty$

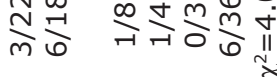

กูก

กู글

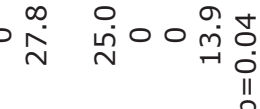

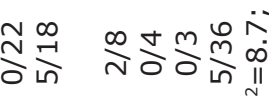

ำกำ

II

กิ่

$\forall \infty \underset{\sim}{N}$

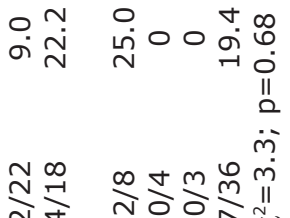

$\ln \operatorname{กำ~}$

mir

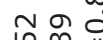

$\stackrel{n}{n} \sum_{\infty}^{\infty} \stackrel{\infty}{N}$

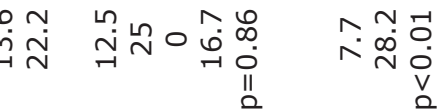

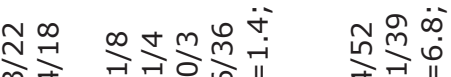

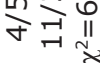

$0 m$ !n 0

mं

$a m$

ขึm

$\sim \infty \infty+m \stackrel{\infty}{\infty}$

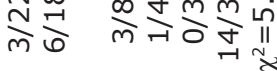

กิน

$\underset{\rightarrow}{\rightarrow} \stackrel{M}{\|}$

نூ

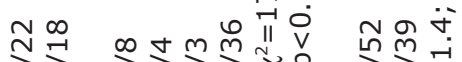

걱레

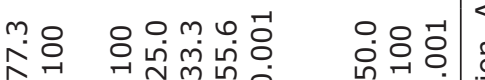

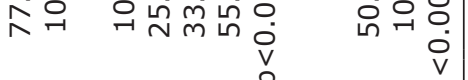

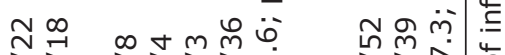

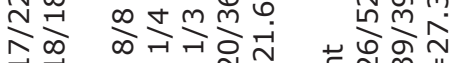

पै

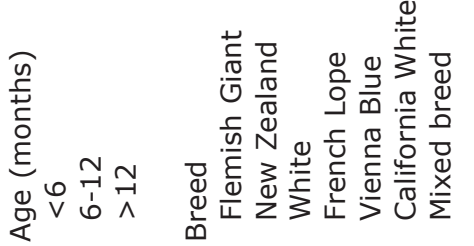

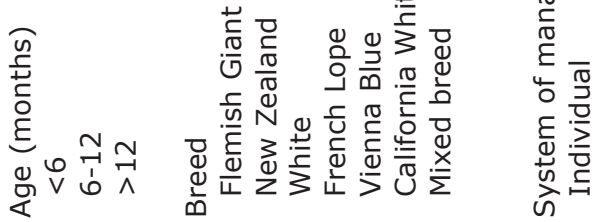

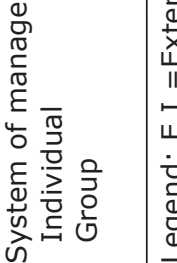


Table-2: Infection intensity (OPG) of rabbits with Eimeria spp. depending on gender.

\begin{tabular}{|c|c|c|c|c|c|c|c|c|c|}
\hline \multirow[t]{2}{*}{ Species } & \multicolumn{4}{|c|}{$\delta$} & \multicolumn{4}{|c|}{ ㅇ } & \multirow[t]{2}{*}{ Mann-Whitney test } \\
\hline & $\mathbf{n}$ & GM & Me & Min.-Max. & $\mathbf{n}$ & GM & Me & Min.-Max. & \\
\hline \multicolumn{10}{|c|}{ Protozoa of the genus Eimeria } \\
\hline Eimeria magna & 13 & 4348 & 5000 & $500-15,500$ & 52 & 5221 & 6000 & $500-26,000$ & $Z=0.77 ; p=0.44$ \\
\hline Eimeria media & 14 & 2215 & 4000 & $200-13500$ & 43 & 2708 & 3500 & $100-15,000$ & $Z=0.28 ; p=0.78$ \\
\hline Eimeria perforans & 7 & 610 & 500 & $500-1000$ & 20 & 1333 & 2000 & $500-5000$ & $Z=2.17 ; p=0.03$ \\
\hline Eimeria stiedae & 3 & 630 & 500 & $500-1000$ & 12 & 652 & 500 & $500-3000$ & $U=17.0 ; p=0.94$ \\
\hline Eimeria coecicola & 4 & 1800 & 1850 & $1000-3500$ & 11 & 730 & 500 & $500-2000$ & $U=4.0 ; p=0.02$ \\
\hline Eimeria exigua & 3 & 1339 & 1000 & $800-3000$ & 9 & 726 & 500 & $100-3000$ & $U=8.0 ; p=0.36$ \\
\hline Eimeria irresidua & 5 & 1084 & 500 & $500-6000$ & 12 & 802 & 500 & $500-2000$ & $U=26.5 ; p=0.75$ \\
\hline $\begin{array}{l}\text { Total } \\
\text { Eimeria spp. }\end{array}$ & 14 & 8982 & 9250 & $1000-35,500$ & 54 & 9076 & 10,000 & $500-35,500$ & $Z=0.21 ; p=0.83$ \\
\hline
\end{tabular}

$\mathrm{OPG}=$ Number of oocysts per gram of feces, $\mathrm{n}=$ Number of infected animals, $\mathrm{GM}=$ Geometric mean, Me=Median

The system of rabbit management also had a significant influence on the intensity of infection. Those kept in groups demonstrated a significantly higher mean intensity of infection of E. magna and of all Eimeria combined than those kept individually $(\mathrm{p}<0.001)$ (Table-5).

\section{Discussion}

The conditions of animal management have a significant influence on the state of infection of farmed rabbits and the course of parasite infestation [7-9]. Parasites have been found to be present in rabbits, even under laboratory conditions, where biosecurity measures are applied strictly [10].

A diagnosis of coccidiosis is confirmed by the presence of a very large number of Eimeria oocysts following stool examination. However, it is not unusual to identify a small number of oocysts in rabbit feces during the microscopic examination, and their presence does not confirm the presence of disease. In addition, number of oocysts excreted by the host is not always correlated with the presence of disease. This is due to the different pathogenicity of individual Eimeria species. The pace of coccidiosis depends primarily on the age of the animal and the virulence of the coccidia species. This is confirmed by our present observations, which revealed no clinical symptoms of disease in rabbits with high-intensity infections.

E. stiedae was found in $16.48 \%$ of the tested rabbits and E. perforans in $29.67 \%$. These species are particularly dangerous for rabbits. E. perforans is known to be responsible for intestinal coccidiosis, characterized by seizures, paralysis, and the subsequent death of the animal, while E. stiedae has been linked to hepatic coccidiosis which, in severe cases, damages the liver, and bile ducts, resulting in death $[8,9,11,12]$.

The extensity of infection for all Eimeria combined was found to be $74.72 \%$; however, some variation has been recorded in previous studies. Ilić et al. [13] reported an Eimeria extensity of $50.65 \%$, while Elshahawy and Elgoniemy [14] reported half our observed extensity among rabbits in Egypt (33.9\%). These differences were most probably related to differences in environmental conditions, such as temperature and humidity. Even so, Szkucik et al. [15] reported similar findings to ours among rabbits in Poland $(78.83 \%)$, but with intestinal coccidiosis dominating $(56.5 \%)$ and significantly greater extensity of E. stiedae infection (3.34\%). Similarly, Abdel-Baki and Al-Quraishy [16] reported 75.0\% extensity of Eimeria in a Saudi Arabian study, and Nosal et al. [17] noted values ranging from 72.0 to 89.6\%; however, the latter also indicated lower mean oocyst intensity than in the present study (487 to 2402 OPG).

A significant difference was found in the infection intensity of E. perforans and E. coecicola between male and female rabbits. These findings confirm those of Pakandl et al. [18] and Papeschi et al. [19], who also reported that the number of oocysts present in feces is correlated with the age, sex, and state of health of the host rabbit.

The age of the rabbit also appears to have a significant influence on the extensity of infection in this study. The greatest extensity was found in rabbits under 6 months of age, and only occasional infection was observed among those aged $<3$ weeks. Pakandl and Hlásková [20] reported no infection with Eimeria among sucking rabbits younger than 19 days. Coccidiosis typically affects younger rabbits aged 5-6 weeks, immediately after weaning, when the young rabbits possess low resistance to infection. The weaning phase is hence a critical period and may lead to significant losses. In addition, the strength of infection intensifies mainly during the perinatal period and before weaning, which is associated with a considerable decrease in immunity. Older rabbits are typically carriers of coccidians [17,21-25]. Similarly, Ilić et al. [13] reported a greater extensity of coccidial infection in young rabbits $(50.6 \%)$ than older ones (37.6\%).

The system of management also has a significant influence on the extensity of Eimeria infection, particularly E. magna, E. media, E. stiedae, and E. irresidua. Significantly greater extensity of infection was observed among rabbits kept in groups than those kept individually. In addition, the rabbits kept in group's also demonstrated greater mean intensity 


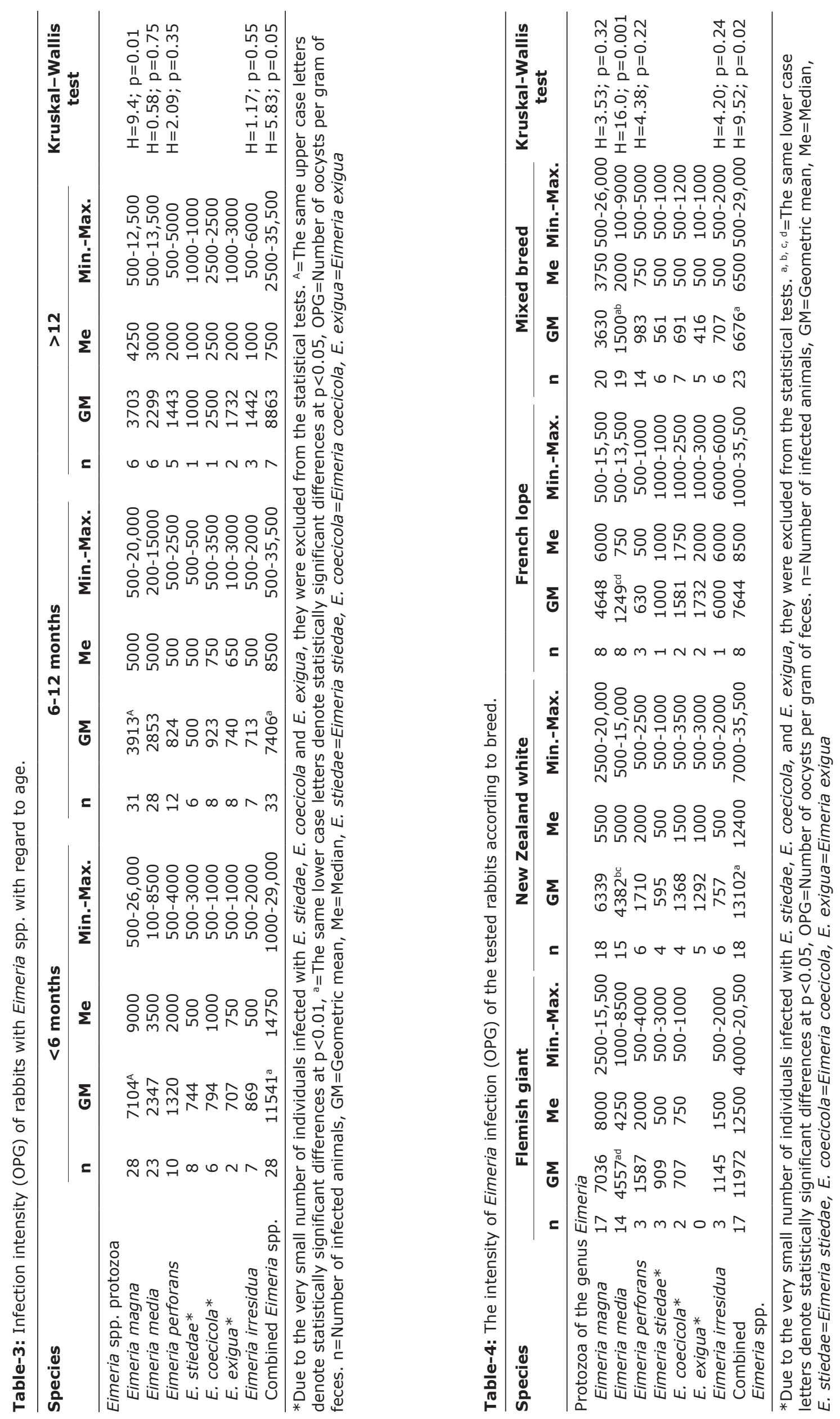


Available at www.veterinaryworld.org/Vol.13/August-2020/24.pdf

Table-5: Infection intensity (OPG) of rabbits with Eimeria spp. according to the system of animal management.

\begin{tabular}{|c|c|c|c|c|c|c|c|c|c|}
\hline \multirow[t]{2}{*}{ Species } & \multicolumn{4}{|c|}{ Individual } & \multicolumn{4}{|c|}{ Group } & \multirow[t]{2}{*}{ Mann-Whitney test } \\
\hline & $\mathbf{n}$ & GM & Me & Min.-Max. & $\mathbf{n}$ & GM & Me & Min.-Max. & \\
\hline Eimeria magna & 26 & 3013 & 3250 & $500-21,000$ & 39 & 7087 & 8000 & $500-26,000$ & $Z=4.30 ; p<0.001$ \\
\hline Eimeria media & 22 & 1915 & 3000 & $100-6000$ & 35 & 3107 & 3500 & $500-15,000$ & $Z=1.59 ; p=0.11$ \\
\hline Eimeria perforans & 14 & 1068 & 1000 & $500-4000$ & 13 & 1111 & 1000 & $500-5000$ & $Z=0.13 ; p=0.90$ \\
\hline Eimeria stiedae & 4 & 595 & 500 & $500-1000$ & 11 & 667 & 500 & $500-3000$ & $\mathrm{U}=21.0 ; \mathrm{p}=0.95$ \\
\hline Eimeria coecicola & 7 & 1148 & 1000 & $500-3500$ & 8 & 771 & 750 & $500-2000$ & $U=18.0 ; p=0.27$ \\
\hline Eimeria exigua & 4 & 707 & 750 & $500-1000$ & 8 & 926 & 900 & $100-3000$ & $U=13 ; p=0.67$ \\
\hline Eimeria irresidua & 6 & 561 & 500 & $500-1000$ & 11 & 1117 & 1500 & $500-6000$ & $U=17.5 ; p=0.13$ \\
\hline All Eimeria spp. & 29 & 5816 & 7000 & $500-24,600$ & 39 & 12588 & 16000 & $1000-35,500$ & $Z=4.50 ; p<0.001$ \\
\hline
\end{tabular}

$\mathrm{OPG}=$ Number of oocysts per gram of feces, $\mathrm{n}=$ Number of infected animals, $\mathrm{GM}=$ Geometric mean, Me=Median

of infection by E. magna, as well as by Eimeria in general. Similarly, Okumu et al. [26] also reported higher infection intensity in rabbits kept in groups and in multi-level cages. Kornaś et al. [27] noted that it is possible to reduce the occurrence of parasites in rabbits kept in cage system; however, this is not the case for Eimeria protozoans due to their short developmental cycle. Sadzikowski et al. [28] reported a significantly higher number of oocysts per gram of feces $(\mathrm{OPG})$ in rabbits kept on individual properties than those kept on breeding farms.

Rabbits with age below 6 months demonstrated significantly higher mean intensity of infection by E. magna and all Eimeria combined than those aged 6-12 months. This is probably due to the fact that different species of rabbit coccidia parasitize different sections of the intestine, and hence the immune response to infection may differ between them [17]. E. perforans, E. media, and E. irresidua induce changes in the duodenum and jejunum, E. magna and E. intestinalis in the iliac gut, and E. flavescens in the cecum and colon. In rabbits, OPG values below 2000 oocysts per gram of feces are considered safe [29]. Varga [30] listed $E$. intestinalis, E. flavescens, and E. stiedae as the most pathogenic species, E. magna, E. irresidua, and E. piriformis as pathogenic and E. perforans, E. coecicola, and E. media as the least pathogenic.

On small-scale farms, coccidiosis can be controlled by the systematic replacement of litter, keeping cages dry, avoiding excessive density of rabbits, using age-rearing systems, as well as by maintaining appropriate temperature and humidity in the cages, and isolating sick individuals. However, Eimeria is resistant to changes in environmental conditions and disinfectants, which almost makes it impossible to completely eliminate them; therefore, cages and water and feed containers should also be regularly cleaned and disinfected, and the feces of rabbits should be regularly checked for the presence of parasites.

\section{Conclusion}

Our findings indicate that Eimeria protozoa are a common occurrence on small-scale rabbit farms. As the coccidiosis treatment does not always give good results, prevention is very important in the fight against this disease. It is necessary to develop a new preventive paradigm that pays special attention to the factors that promote the spread and development of infection in this type of farm. For example, it would be recommended to use large, dry, and bright rooms with access to the sun, as these are conducive to preventing the occurrence of coccidia.

\section{Authors' Contributions}

BP designed the concept of research, performed the parasitological analysis, drafted the manuscript, analyzed, and interpreted data. AT designed the concept of research, drafted the manuscript, and revised the manuscript. RP designed the concept of research, performed the statistical analysis of all data. EJ designed the concept of research and coordinated the collection of the samples. PS, BS, and PSa collected the samples and data. All authors read and approved the final manuscript.

\section{Acknowledgments}

We are very grateful to the breeders for enabling us to carry out this research on their farms. The research was financed by the statutory funding of the Department of Animal Reproduction Biotechnology and Environmental Hygiene, West Pomeranian University of Technology, Szczecin, Poland.

\section{Competing Interests}

The authors declare that they have no competing interests.

\section{Publisher's Note}

Veterinary World remains neutral with regard to jurisdictional claims in published institutional affiliation.

\section{References}

1. Sharma, K.G., Vidyarthi, V.K., Archana, K. and Zuyie, R. (2016) Probiotic supplementation in the diet of rabbits a review. Livest. Res. Int., 4(1): 1-10.

2. Ogolla, K.O., Gathumbi, P.K., Waruiru, R.M., Kumu, P.O., Chebet, J. and Kitala, P.H.M. (2018) Efficacy of sulphachloropyrazine, amprolium hydrochloride, trimethoprim-sulphamethoxazole, and diclazuril against experimental and natural rabbit coccidiosis. J. Vet. Med., 2018: Article ID 5402469.

3. García-Rubio, V., Bautista-Gómez, L.G., Martínez-Castañeda, 
J.S. and Romero-Núñez, C. (2017) Multicausal etiology of the enteric syndrome in rabbits from Mexico. Rev. Argent. Microbiol., 49(2): 132-138.

4. Renaux, S., Quéré, P., Buzoni-Gatel, D., Sewald, B., Le Vern, Y., Coudert, P. and Drouet-Viard, F. (2003) Dynamics and responsiveness of T-lymphocytes in secondary lymphoid organs of rabbits developing immunity to Eimeria intestinalis. Vet. Parasitol., 110(3-4): 181-195.

5. Anonym. (1986) Manual of Veterinary Parasitological Laboratory Techniques. MAFF, London.

6. Pellerdy, L.P. (1974) Coccidia and Coccidiosis. $2^{\text {nd }} e d$. Verlag Paul Parey, Berlin.

7. Elshahawy, I., El-Goniemy, A. and Ali, E. (2016) Epidemiological survey on mange mite of rabbits in the Southern Region of Egypt. Sains Malays., 45(5): 745-751.

8. Dogo, G.I.A., Karaye, P.G., Patrobas, M.G., Galadima, M. and Gosomji, I.J. (2017) Prevalence of gastrointestinal parasites and their impact in domestic animals in Vom, Nigeria. Saudi. J. Med. Pharm. Sci., 3(3): 211-216.

9. Prakash, M.A., Soundararajan, C., Nagarajan, K., Gnanaraj, P.T. and Saravanakumar, V.R. (2017) Sarcoptic mange infestation in rabbits in an organized farm at Tamil Nadu. J. Parasit. Dis., 41(2): 429-432.

10. Bugti, A.G., Shah, M.A., Kaleri, H.A., Iqbal, M.A., Samo, A.K., Kaleri, R.R., Goswami, N. and Arijo, A.G. (2016) Prevalence of gastrointestinal parasites of laboratory animals at animal house. J. Agric. Biotechnol., 1(1): 26-28.

11. Jańczak, D., Barszcz, K. and Cielecka, D. (2015) Infestations with the nematodes in domestic and laboratory rodents and lagomorphs. Życie Wet., 90(5): 302-306.

12. Indrasanti, D., Indradji, M., Hastuti, S., Aprilliyani, E., Fatikha, F. and Rosyadi, K.A. (2017) The administration of garlic extract on Eimeria stiedae oocysts and the hematological profile of the Coccidia infected rabbits. Med. Peternakan, 40(3): 158-164.

13. Ilić, T., Stepanović, P., Nenadović, K. and Dimitrijević, S. (2018) Improving agricultural production of domestic rabbits in Serbia by follow-up study of their parasitic infections. Iran. J. Vet. Res., 19(4): 290-297.

14. Elshahawy, I. and Elgoniemy, A. (2018) An epidemiological study on endoparasites of domestic rabbits (Oryctolagus cuniculus) in Egypt with special reference to their health impact. Sains Malays., 47(1): 9-18.

15. Szkucik, K., Pyz-Łukasik, R., Szczepaniak, O.K. and Paszkiewicz, W. (2014) Occurrence of gastrointestinal parasites in slaughter rabbits. Parasitol. Res., 113(1): 59-64.

16. Abdel-Baki, A.S. and Al-Quraishy, S. (2013) Prevalence of Coccidia (Eimeria spp.) infection in domestic rabbits, Oryctolagus cuniculus, in Riyadh, Saudi Arabia. Pak. J. Zool., 45(5): 1329-1333.
17. Nosal, P., Kowal, J., Nowosad, B., Bieniek, J. and Kowalska, D. (2009) Dynamics of endoparasite infections in rabbit sat different reading regimes. Wiad. Parazytol., 55(2): 173-177.

18. Pakandl, M., Hláskovám, L., Poplštein, M., Chromá, V., Vodička, T., Salát, J. and Mucksová, J. (2008) Dependence of the immune response to coccidiosis on the age of rabbit suckling. Parasitol. Res., 103: 1265-1271.

19. Papeschi, C., Fichi, G. and Perrucci, S. (2013) Oocystexcretionpattern of three intestinal Eimeria species in female rabbits. World Rabbit Sci., 21(2): 77-83.

20. Pakandl, M. and Hlásková, L. (2007) The reproduction of Eimeria flavescens and Eimeria intestinalis in suckling rabbits. Parasitol. Res., 101(5): 1435-1437.

21. Drouet-Viard, F., Coudert, P., Licois, D. and Boivin, M. (1997) Vaccination against Eimeria magna coccidiosis using spray dispersion of precocious line oocysts in the nest box. Vet. Parasitol., 70(1-3): 61-66.

22. Połozowski, A. (1993) Coccidiosis of rabbits and its control. Wiad Parazytol, 39(1): 13-28.

23. Heker, M.M., Nakamura, A.A., Santana, B.N. and Meireles, M.V. (2017) Etiological aspects of Eimeria spp. infection in Brazilian rabbit (Oryctolagus cuniculus) farms. Vet. Parasitol. Reg. Stud. Reports, 8: 78-81.

24. Ola-Fadunsin, S.D., Hussain, K., Rabiu, M. and Ganiyu, I.A. (2018) Parasitic conditions of domestic owned rabbits in Osun state, Southwestern Nigeria: Retrospective evaluation, risk factors and co-infestations. Int. J. Vet. Sci. Med., 6(2): 208-212.

25. Maziz-Bettahar, S., Aissi, M., Ainbaziz, H., Bachene, M.S., Zenia, S. and Ghisani, F. (2018) Prevalence of coccidian infection in rabbit farms in north Algeria. Vet. World, 11(11): 1569-1573.

26. Okumu, P.O., Gathumbi, P.K., Karanja, D.N., Mande, J.D., Wanyoike, M.M., Gachuiri, C.K., Kiarie, N., Mwanza, R.N. and Borter, D.K. (2014) Prevalence, pathology and risk factors for coccidiosis in domestic rabbits (Oryctolagus cuniculus) in selected regions in Kenya. Vet. Q., 34(4): 205-210.

27. Kornaś, S., Kowal, J., Wierzbowska, I., Basiaga, M., Nosal, P. and Niedbała, P. (2015) The Alice follow the white rabbit parasites of farm rabbits based on coproscopy. Ann. Parasitol., 61(4): 257-261.

28. Sadzikowski, A.B., Szkucik, K., Szczepaniak, K.O. and Paszkiewicz, W. (2008) Prevalence of protozoon genus Eimeria in slaughter rabbits. Med. Weter., 64(12): 1426-1429.

29. Kowalska, D., Bielański, P. and Grzegorzek, I. (2012) Natural alternatives to coccidiostats in rabbit nutrition. Przegl. Hod. 5-6(80): 19-23.

30. Varga, I. (1982) Large-scale management and parasite populations: Coccidia in rabbit. Vet. Parasitol., 11(1): 69-84. 